\title{
Citotoxicity of food dyes Sunset Yellow (E-110), Bordeaux Red (E-123), and Tatrazine Yellow (E-102) on Allium cepa L. root meristematic cells
}

\author{
Citotoxicidade dos corantes alimentares Amarelo Crepúsculo (E-110), Vermelho Bordeaux (E-123) \\ e Amarelo Tartrazina (E-102) em células meristemáticas de raízes de Allium cepa L.
}

Keiva Maria Silva GOMES ${ }^{1}$, Maria Virna Gonçalves Aguiar de OLIVEIRA Francisco Ronielson de Sousa CARVALHO ${ }^{1}$, Camila Carvalho MENEZES ${ }^{1}$, Ana Paula PERON ${ }^{1 \star}$

\begin{abstract}
The objective of this study was to evaluate the cytotoxic effect of the food dyes sunset yellow, bordeaux red, and tartrazine yellow on the cellular cycle of Allium cepa L. Each dye was evaluated at the doses of 0.4 and $4.0 \mathrm{~mL}$, at the exposure times of 24 and 48 hours in root tip cells of Allium cepa L. Slides were prepared and cells were analyzed during the whole cell cycle for cellular aberrations totaling 5,000 total cells for each dose evaluated. The mitotic index was calculated, and statistical analysis was performed using the Chi-squared test ( $\mathrm{p}<0.05)$. The results showed that the three dyes used under the evaluated doses and exposure times were cytotoxic to the cells of the system-test used. Further cytotoxicity studies should be conducted for additional results and a proper evaluation of the effect of these three dyes on a cellular level.

Keywords: food additive; cytotoxicity; Allium cepa.
\end{abstract}

\section{Resumo}

Este estudo teve por objetivo avaliar o efeito citotóxico dos corantes alimentares amarelo crepúsculo, vermelho bordeaux e amarelo tartrazina sobre o ciclo celular de Allium cepa L. Cada corante foi avaliado nas doses de 0,4 e 4,0 mL, nos tempos de exposição de 24 e 48 horas, em células de pontas de raízes de Allium cepa L. Prepararam-se lâminas e analisaram-se células, em todo o ciclo celular, e a presença de aberrações celulares, totalizando 5.000 células para cada dose avaliada. Foi calculado o índice mitótico e a análise estatística foi feita por meio do teste quiquadrado $(\mathrm{p}<0,05)$. Os resultados mostraram que os três corantes, nas doses e tempos de exposição avaliados, foram citotóxicos às células do sistema-teste utilizado. Estudos adicionais de citotoxicidade devem ser conduzidos para se somar a estes resultados e, assim, avaliar, com propriedade, a ação destes três corantes em nível celular.

Palavras-chave: aditivo alimentar; citotoxicidade; Allium cepa.

\section{Introduction}

Dyes are a class of food additives without nutritional value which are added to foods with the objective of providing color thus making the product more attractive and increasing its consumer acceptability (POLÔNIO; PERES, 2009). For that reason, the use of dyes is one of the most controversial advances for the food industry because, from a health point of view, such dyes, mainly the artificial ones, are not recommended (SILVA; REED, 2010; CHEESEMAN, 2012).

However, according to Marmitt, Pirottas and Stulp (2010), in spite of resistance of some specialists to the ingestion of these additives, the estimate of food dye and pigment production is from 750 to 800 thousand tons a year, of which 26 thousand, on average, are consumed only in Brazil.

On a worldwide basis, the control of the use of food dyes is based on the Acceptable Daily Intake (ADI), which is based on the results of international research and the recommendations of the Codex Committee on Food Additives and Contaminants (CCFAC) (BESSONOV et al., 2011; GANESAN et al., 2011).
In Brazil, permission for use and determination of tolerable maximum levels of food additives is the responsibility of the National Agency of Health Surveillance (ANVISA) and the Ministry of Health, which conduct these inspection activities through the Standing Committee on Food Additives (CPAA) (FÁVERO; RIBEIRO; AQUINO, 2011).

However, in spite of the control demanded by these regulatory agencies, the use of dyes in foods still raises a series of doubts as to their toxicity. This is due to the great difficulty in verifying whether the amount of additives used by the food industry are in accordance with the current laws (ANVISA for example) since in Brazil it is not mandatory to declare the amount of dyes present in the products on the label; only a list of the additives used have to be declared (BRASIL, 2005).

Among the most commonly used dyes by the food industry are those that contain an Azo group $(-\mathrm{N}=\mathrm{N}-)$ including the sunset yellow, the bordeaux red, and the tartrazine yellow. These dyes are extensively used in cereals, candies, dairy products,

Received 16/7/2012

Accepted 21/1/2013 (005793)

${ }^{1}$ Núcleo de Pesquisa Aplicada a Saúde e ao Meio-ambiente, Laboratório de Citogenética Vegetal e Animal, Universidade Federal do Piauí - UFPI, Campus Senador Helvídio

Nunes de Barros, Rua Cícero Duarte, 940, Bairro Junco, CEP 64600-000, Picos, PI, Brasil, e-mail: anpapegenpes@hotmail.com

${ }^{*}$ Corresponding author 
jellies, ice creams, fillings, liqueurs, powdered juices, soft drinks, and yogurts (MEINICKE, 2008).

In the past decade, these three dyes have caused controversy as to their toxic effects, and their use was forbidden in some countries such as the United States and Japan, where from the results of bioassays with mammals, they were shown to be mutagenic and even carcinogenic (FENG; CERNIGLIA; CHEN, 2012). However, in toxicological evaluations in other countries, such as in England and Brazil, they did not show significant cytotoxicity in tests with rodents and continue to be marketed freely (ORSOLIN; NEPOMUCENO, 2009; MORRISON; WRIGHT; JOHN, 2012). Thus, according to Rutkunas, Sabaliauskas and Mizutani (2010), studies on the adverse health effects caused by artificial dyes, mainly those of the azo group, are insufficient and quite contradictory, and, as such, additional studies on various system-tests such as mammals, plants, insects, and in vitro cell culture should be conducted to assess the true effect of these food additives on a cellular level.

Due to the diversity of substances with the capacity to dye, the list of food dyes allowed in each country varies substantially. According to the current legislation, through Resolution No. 388, of August 9, 1999, of ANVISA, for food and drink, the use of only eleven artificial dyes are allowed in Brazil, namely Erythrosine, included in the class of xanthene dyes; indigo blue, included in the class of indigoid dyes; patent blue V, fast green; and brilliant blue included in the class of triphenilmetane dyes; bordeaux red, ponceau 4R, red 40, azorrubine, tartrazine yellow and sunset yellow, included in the class of azo dyes (BRASIL, 2005).

The bioassays with plants have been considered quite sensitive and simple in the monitoring of the cytotoxic effects of chemical compounds (USEPA) (GRANT, 1999; IGANCI et al., 2006), and the Allium cepa (onion) has been indicated as an efficient system-test for cytotoxicity evaluation (LEME; MARINMORALES, 2008) due to its kinetic proliferation properties and to its reduced number $(2 n=16)$ of large chromosomes and other characteristics, which facilitates its analysis for the detection of damage to the DNA molecule structure (MATSUMOTO et al., 2006, CARITÁ; MARIN-MORALES, 2008; HERRERO; PEREZ; FERNÁNDEZ, 2012) and changes in the cell division index (mitotic index ), such as the increase or reduction in the proliferation of tissue cells exposed to chemical compounds (GADANO et al., 2002; TABREZ et al., 2011), and also for demonstrating satisfactory similarity to the results obtained with other bioassays such as those conducted with animals and cell cultures (NUNES et al., 2011; ARUNG et al., 2011; GERAS'KIN et al., 2011).

Therefore, due to the wide industrial use of the food dyes tartrazine yellow, bordeaux red, and sunset yellow in the coloration of foods, the need for additional studies and the deep involvement of researchers in the evaluation of the effect of these dyes on a cellular level and considering the Allium cepa system as an appropriate bioassay for evaluation of cytotoxicity of chemical compounds, the objective of this study was to analyze the cytotoxic effect of these three food dyes on Allium cepa L. root meristematic cells.

\section{Materials and methods}

This study was developed at the Plant and Animal Cytogenetics Laboratory of the Senador Helvídio Nunes de Barros Campus of the Federal University of Piauí, Picos Municipal District, State of Piauí, from October, 2010 to June, 2011.

The flasks containing $10 \mathrm{~mL}$ of the tartrazine yellow, bordeaux red, and sunset yellow dyes (Mix Coralin, Brazil, São Paulo) were purchased at a bakery supply store in the municipal district of Picos, PI. They were evaluated them in the form in which they are used by the population. The dye solution of each flask was made up of $90 \%$ of the dye of interest and $10 \%$ of other sugars.

Two doses of each dye were determined based on the recommendations on the label of the flasks, which was $10 \mathrm{~mL}$ dye per $2 \mathrm{~kg}$ of mass. Thus, the volume of $10 \mathrm{~mL}$ was estimated from the weight of each onion bulb that was on average $0.08 \mathrm{~kg}$. The first dose established for each of the dyes studied was 0.4 $\mathrm{mL}$ and the second was 10 times higher than the first, $4 \mathrm{~mL}$.

Onion bulbs (Allium cepa L.) were allowed to germinate in flasks with distilled water, at room temperature $\left( \pm 25^{\circ} \mathrm{C}\right)$, and under aeration until the roots reached about $1.0 \mathrm{~cm}$ of length.

For the analysis of each dose, an experimental group was established with five onion bulbs. The analyses consisted of two groups of bulbs, one of 0.4 and one of $4 \mathrm{~mL}$, for each dye evaluated. Before putting the roots of the bulbs in contact with their respective treatment doses, four roots, on average, were collected and fixed to serve as control (CO).

Next, the roots of each bulb were placed in their respective treatment doses for 24 hours, this procedure was denominated 24-hour exposure time (ET 24h). After this period of time, four roots, on average, were removed and fixed. Subsequently, the remaining roots of each bulb were again placed in their respective treatment doses where they remained for 24 more hours; this procedure was denominated 48-hour exposure time (ET 48h). Next, the roots of each onion bulb were again collected and fixed. Root fixation was carried out in Carnoy 3:1 (ethanol: acetic acid) for approximately 6 hours.

After fixation, the roots were submitted to acid hydrolysis for 8 minutes and then stained with acetic orcein. Next, cytology slides were prepared according to the protocol by Guerra and Souza (2002). For each root, one slide was prepared and its analysis was carried out under an EK 2000 optical microscope at $40 \mathrm{X}$, where the number of cells under division, the number of cells in interfase, and the presence of cellular aberrations were observed.

A total of 1000 cell bulbs of each experimental group were analyzed totaling 5000 cells per group. Mitotic index was calculated by the number of cells under division, divided by total number of cells analyzed. The statistical analysis of the data was carried out by the Chi-square test at $5 \%$ significance level using the BioEstat statistical program (AYRES et al., 2007). 


\section{Results}

Table 1 shows the number of cells in interphase, in different phases of cell division, and the mitotic index values obtained from the root meristematic cells of Allium cepa treated with water and with the food dyes sunset yellow, bordeaux red, and tartrazine yellow under exposure times of 24 and 48 hours. The results shown in Table 1 include the $\chi^{2}$ values obtained.

The significant values of $\chi^{2}$ obtained between $\mathrm{CO}$ and exposure times and between the exposure times evaluated were also included in the results.

It can be seen that the mitotic index value obtained for the Sunset Yellow dye at the dose of $0.4 \mathrm{~mL}$ for ET $48 \mathrm{~h}$, differed significantly from that of the mitotic index of its $\mathrm{CO}\left(\chi^{2}=10.97\right)$ and ET $24 \mathrm{~h}\left(\chi^{2}=9.38\right)$ (Table 1$)$. At the dose of $4.0 \mathrm{~mL}$ of this dye, the cell division indexes of ET $24 \mathrm{~h}\left(\chi^{2}=3.85\right)$ and ET $48 \mathrm{~h}$ $\left(\chi^{2}=4.32\right)$ also differed significantly from those of the control group.

With regard to the data obtained for the bordeaux red food dye (Table 1), at the dose of $0.4 \mathrm{~mL}$, the cell division index of ET $48 \mathrm{~h}$ differed statistically from the cell division index of its $\mathrm{CO}\left(\chi^{2}=5.76\right)$ and from the mitotic index obtained for ET $24 \mathrm{~h}$ $\left(\chi^{2}=4.44\right)$. Similarly, with the application of the $4.0 \mathrm{~mL}$ dose, the mitotic index values obtained for ET $24 \mathrm{~h}\left(\chi^{2}=8.63\right)$ and for ET $48 \mathrm{~h}\left(\chi^{2}=9.73\right)$ had lower values than that of the control. With the application of $4.0 \mathrm{~mL}$ at ET $48 \mathrm{~h}$ for the tartrazine yellow dye there was a significant reduction in the mitotic index as compared to its respective $\mathrm{CO}\left(\chi^{2}=6.29\right)$ and to ET $24 \mathrm{~h}$ $\left(\chi^{2}=4.35\right)$, thus demonstrating a cell proliferation inhibition with the increase of the dye concentration and its exposure time.

Table 2 shows the number of micronucleated cells with bridges in anaphase- and telophase and the total number of chromosomal aberrations present in the Allium cepa L. root meristematic cells treated with water and with the food dyes sunset yellow, bordeaux red, and tartrazine yellow under the exposure times of 24 and 48 hours.

Sunset yellow, bordeaux red, and tartrazine yellow dyes at the two doses and under the two exposure times evaluated had a statistically significant number of cellular aberrations as compared to their controls. However, when comparing the values of cellular aberrations between the two exposure times, at the two doses evaluated, it was observed that the result was not statistically significant for any of the dyes under study.

\section{Discussion}

The azo group dyes present a naphthalene ring connected to a second benzene ring by an azo bond $(\mathrm{N}=\mathrm{N})$. Those rings can contain one, two, or three sulfonic groups. This dye group, globally, represents the class of the most commonly used synthetic dyes by the food industry, mainly sunset yellow, bordeaux red and tartrazine yellow dyes (MORRISON; WRIGHT; JOHN, 2012).

These three dyes are controversial in relation to their toxic activity and attract the interest of toxicologists and allergists. They are seen as responsible for various immunological reactions causing urticaria (hives) or even asthma. It is estimated that one person in 10 thousand people have adverse reactions to these dyes (WORLD..., 2005). According to Sayed et al. (2012), it is suspected that a significant correlation exists between the mutagenic effect of azo group food dyes and the triggering of various human pathologies.

The sunset yellow food dye is synthesized from coal tar and azoic paints. This dye, as mentioned by Sardi et al. (2010),

Table 1. Total number of cells analyzed in the cell cycle of root tip cells Allium cepa treated with 0.4 and $4.0 \mathrm{~mL}$ of the food dyes sunset yellow, bordeaux red, and tartrazine yellow at exposure times of 24 and 48 hours

\begin{tabular}{|c|c|c|c|c|}
\hline Dye/Dose & Exposure times & Cells in interphase & Cells under division & Mitotic index (\%) \\
\hline Sunset Yellow & $\mathrm{CO}$ & 4,015 & 985 & $19.7^{\mathrm{a}}$ \\
\hline \multirow[t]{2}{*}{$0.4 \mathrm{~mL}$} & ET $24 \mathrm{~h}$ & 4,100 & 900 & $18.0^{\mathrm{a}}$ \\
\hline & ET $48 \mathrm{~h}$ & 4,750 & 250 & $5.0^{\mathrm{b}}$ \\
\hline Sunset Yellow & $\mathrm{CO}$ & 4,400 & 600 & $12.0^{\mathrm{a}}$ \\
\hline \multirow[t]{2}{*}{$4.0 \mathrm{~mL}$} & ET $24 \mathrm{~h}$ & 4,740 & 260 & $5.2^{\mathrm{b}}$ \\
\hline & ET $48 \mathrm{~h}$ & 4,760 & 240 & $4.8^{\mathrm{b}}$ \\
\hline Bordeaux Red & $\mathrm{CO}$ & 4,525 & 475 & $9.5^{\mathrm{a}}$ \\
\hline \multirow[t]{2}{*}{$0.4 \mathrm{~mL}$} & ET $24 \mathrm{~h}$ & 4,705 & 295 & $5.9^{\mathrm{a}}$ \\
\hline & ET $48 \mathrm{~h}$ & 4,895 & 105 & $2.1^{\mathrm{b}}$ \\
\hline Bordeaux Red & $\mathrm{CO}$ & 4,455 & 545 & $10.9^{\mathrm{a}}$ \\
\hline \multirow[t]{2}{*}{$4.0 \mathrm{~mL}$} & ET $24 \mathrm{~h}$ & 4,400 & 60 & $1.2^{\mathrm{b}}$ \\
\hline & ET $48 \mathrm{~h}$ & 4,700 & 30 & $0.6^{\mathrm{b}}$ \\
\hline Tartrazine Yellow & $\mathrm{CO}$ & 4,475 & 525 & $10.5^{\mathrm{a}}$ \\
\hline \multirow[t]{2}{*}{$0.4 \mathrm{~mL}$} & ET $24 \mathrm{~h}$ & 4,620 & 380 & $7.6^{\mathrm{a}}$ \\
\hline & ET $48 \mathrm{~h}$ & 4,650 & 350 & $7.0^{\mathrm{a}}$ \\
\hline Tartrazine Yellow & $\mathrm{CO}$ & 4,563 & 437 & $8.7^{\mathrm{a}}$ \\
\hline \multirow[t]{2}{*}{$4.0 \mathrm{~mL}$} & ET $24 \mathrm{~h}$ & 4,667 & 333 & $6.7^{\mathrm{a}}$ \\
\hline & ET $48 \mathrm{~h}$ & 4,935 & 65 & $1.3^{\mathrm{b}}$ \\
\hline
\end{tabular}

CO - Control; ET - Exposure time. Means followed by the same letter do no differ significantly by the chi-square test $(\mathrm{P} \leq 0.05)$ 
Table 2. Number of micronucleated cells with bridges in anaphase and telophase and total number of aberrant cells treated with 0.4 and $4.0 \mathrm{~mL}$ of the food dyes sunset yellow, bordeaux red, and tartrazine yellow at exposure times of 24 and 48 hours.

\begin{tabular}{|c|c|c|c|c|}
\hline Dye/Dose & Exposure Time & Bridges in Anaphase and Telophase & Micronucleated Cells & Total Number of Aberrant Cells \\
\hline Sunset Yellow & $\mathrm{CO}$ & 00 & 00 & $00^{\mathrm{b}}$ \\
\hline \multirow[t]{2}{*}{$0.4 \mathrm{~mL}$} & ET $24 \mathrm{~h}$ & 00 & 12 & $12^{\mathrm{a}}$ \\
\hline & ET $48 \mathrm{~h}$ & 05 & 06 & $11^{\mathrm{a}}$ \\
\hline \multirow[t]{2}{*}{$4.0 \mathrm{~mL}$} & ET $24 \mathrm{~h}$ & 02 & 12 & $14^{\mathrm{a}}$ \\
\hline & ET $48 \mathrm{~h}$ & 02 & 08 & $10^{\mathrm{a}}$ \\
\hline $0.4 \mathrm{~mL}$ & ET $48 \mathrm{~h}$ & 00 & 16 & $16^{\mathrm{a}}$ \\
\hline Bordeaux Red & $\mathrm{CO}$ & 00 & 00 & $00^{\mathrm{b}}$ \\
\hline \multirow[t]{2}{*}{$4.0 \mathrm{~mL}$} & ET $24 \mathrm{~h}$ & 05 & 12 & $17^{\mathrm{a}}$ \\
\hline & ET $48 \mathrm{~h}$ & 04 & 10 & $14^{\mathrm{a}}$ \\
\hline Tartrazine Yellow & $\mathrm{CO}$ & 00 & 00 & $00^{\mathrm{b}}$ \\
\hline $4.0 \mathrm{~mL}$ & ET $48 \mathrm{~h}$ & 06 & 12 & $18^{\mathrm{a}}$ \\
\hline
\end{tabular}

$\mathrm{CO}$ - Control; ET - Exposure Time. The number of cells with the same letter do not differ significantly by the chi-square test $(\mathrm{P} \leq 0.05)$.

can cause anaphylactic shock, angioedema, vasculitis, and thromboxane synthesis inhibition in people sensitive to its composition; it can enhance aggressive behavior in children, and trigger serious allergic reactions in people that have sensibility to paracetamol, acetylsalicylic acid, and sodium benzoate.

As for its cytotoxicity, a study conducted by Sayed et al. (2012) demonstrated the mutagenic action of this dye in mice with significant chromosomal aberration values in the liver and germinative cells, DNA fragmentation, and increase of morphological abnormalities in spermatozoids of those animals. Poul et al. (2009) also verified the mutagenic action in intestine cells of rodents when orally treating mice with sunset yellow, bordeaux red, and tartrazine yellow dyes.

These two studies corroborate the data obtained in the present study on the induction of cellular aberrations at the two doses tested of the sunset yellow dye under the exposure times of 24 and 48 hours, and they reinforce the potential to trigger mutagenic action in the cells. However, Sasaki et al. (2002), evaluating the sunset yellow food dye, found different from the results obtained in this study and those found by other researchers; he verified that the same did not induce the emergence of cellular aberrations in stomach cells of mice treated orally at the maximum allowed dosage of $2.000 \mathrm{mg} / \mathrm{kg}$.

Another dye controversial in scientific circles is bordeaux red, synthesized from coal tar. Some time ago this dye aroused controversy about its toxicity in laboratory animals, and its use was prohibited in some countries; however, it is still used extensively in others, for instance, in Brazil (MEINICKE, 2008; NI; WANG; KOKOT, 2009).

In a study carried out by Sarikaya, Selvi and Erkoç (2012), investigating the effect of the dye bordeaux red in
Drosophila melanogaster larvae, it can be verified that this dye caused somatic mutations in these organisms. Mpountoukas et al. (2010) conducted an experiment on human peripheral blood cell cultures evaluating the cytotoxic effect of the bordeaux red, erythrosine, and tartrazine yellow food dyes, and they found that the three dyes under study caused mitotic index reduction and induced the emergence of cellular aberrations, e.g. micronuclei, in those cells. Shimada et al. (2010) evaluated the effect of the bordeaux red dye at various concentrations on the colon cells of rats and mice, and they verified that all the doses tested caused chromosomal aberrations and reduction in the cell division index of the tissue cells evaluated in those animals.

The 90's were marked by special attention given to the cytotoxicity of the food dye tartrazine yellow due to its antiproliferative activity and potential to cause structural chromosomal aberrations (MEINICKE, 2008) which is in agreement with the results obtained for the root meristematic cells of Allium cepa in the present study.

In addition to the studies of Sasaki et al. (2002) and Mpountoukas et al. (2010) previously mentioned, other studies have already been conducted evaluating the effect of the tartrazine dye on a cellular level, such as the study conducted by Polonio and Peres (2009), who evidenced the mutagenic potential of this dye in in vitro cultures of human stomach cells. They also observed that this food dye changes the turnover rate of the human stomach cells during their normal growth, and they also interfere in their regenerative hyperplasia process and thus contribute to the development of gastric cancer.

In another study conducted by Moutinho, Bertges and Assis (2007), it was verified that being a nitrous derivative, the dye tartrazine demonstrated to have mutagenic and carcinogenic potential in rodents; these authors, investigating a treatment 
with this dye in Wistar rats, chronically and orally, verified that the tartrazine produces aromatic amine and sulphanilic acid, products with cytotoxic potential in the organism of these animals after being metabolized by their gastrintestinal microflora.

The results related to tartrazine yellow dye obtained in the present study indicate that it has antiproliferative activity action and potential to cause cellular aberrations, which confirm the results obtained by other researchers in other system-tests indicating that this food additive has cytotoxic activity.

The results obtained in the present research reinforce the importance of the Allium cepa system-test since, as verified in this study, it presents results similar to those obtained with other bioassays. It is also important to point out, as mentioned by Vicentini et al. (2001), Peron, Marcu and Vicentini (2008) and Fachinneto et al. (2009), that even if the plant metabolism is different, the results of this system-test are excellent cytotoxic analysis parameters, and that the observation of the occurrence of chromosomal alterations in the cellular cycle of this vegetable species has been used as an indicator to warn people about the consumption of certain foods and synthetic and natural medicines.

It is known that the food industry is one of the fastest growing economic interfaces in the world generating a high competitiveness among producers that strive to meet new consumers' demands. As a result, they try to produce foods attractive from the hygienic, nutritional, and sensory point of view.

However, with the objective of becoming competitive, they use more and more food additives, which are considered any ingredient intentionally added to the foods to modify their physical, chemical, biological, or sensorial characteristics without a nutritional purpose. Since the food dyes are classified as additives and, therefore, are only directly related to the improvements in the appearance of foods, the competent supervisory authorities should establish stricter standards to assure that the proper amounts of these ingredients are being used by the food industry and stimulate, increasingly, studies on toxicity of these additives because inappropriate use of these chemicals can cause adverse health effects for consumers.

\section{Conclusion}

The results obtained in the present study indicated cytotoxic activity of the dyes sunset yellow, bordeaux red, and tartrazine yellow on root meristematic cells of Allium cepa. These findings are in agreement with others reported in the scientific literature indicating that the use of these three food additives by the population requires greater scrutiny.

Therefore, further studies are necessary varying the doses, exposure times, and system-tests to accurately evaluate the potential risks of the mutagenic agents present in the composition of these food additives. These results are important to advise the committees responsible for the ADIs, such as FAO/WHO, JECFA, and ANVISA, on the establishment of appropriate tolerable limits for the use of these food additives.

\section{References}

ARUNG, E. T. et al. Melanin biosynthesis inhibitory and antioxidant activities of quercetin-3'-O-beta-D-glucose isolated from Allium cepa. Zeitschrift fur Naturforschung $\mathrm{C}$ Journal of biosciences, v. 66, n. 5-6, p. 209-14, 2011.

AYRES, M. et al. BioEstat 5.0 - Aplicações Estatísticas nas Áreas das Ciências Biológicas e Médicas: Sociedade Civil Mamirauá, Belém. Brasília: CNPq, 2007.

BESSONOV, V. V. et al. Development of methods for determining acrylamide in food products by gas-liquid chromatography. Voprosy Pitanni, v. 80, p. 4, p. 70-83, 2011.

CARITÁ, R.; MARIN-MORALES, M. A. Induction of chromosome aberrations in the Allium cepa test system caused by the exposure of seeds to industrial effluents contaminated with azo dyes. Chemosphere, v. 72, p. 722-25, 2008. http://dx.doi.org/10.1016/j. chemosphere.2008.03.056

CHEESEMAN, M. A. Artificial food color additives and child behavior. Environmental Health Perspectives, v. 20, n. 1, p. 15-16, 2012. http://dx.doi.org/10.1289/ehp.1104409

BRASIL. Agência Nacional de Vigilância Sanitária. Resolução da Diretoria Colegiada - RDC n²17, de 29 de julho de 2005. Diário Oficial da República Federativa do Brasil, Brasília, DF, 01 ago. 2005. Disponível em: <http://www.anvisa.gov.br/legis/ resol/2005/rdc/21705rdc.pdf >. Acesso em: 22 maio 2012.

FÁVERO, D. M.; RIBEIRO, C. S. G.; AQUINO, A. D. Sulfitos: importância na indústria alimentícia e seus possíveis malefícios a população. Segurança Alimentar e Nutricinal, v. 18, n. 1, p. 11-20, 2011.

FENG, J.; CERNIGLIA, C. E.; CHEN, H. Toxicological significance of azo dye metabolism by human intestinal microbiota. Frontiers in Bioscience (Elite Edition), v. 1, n. 4, p. 568-86, 2012.

GADANO, A. et al. In vitro genotoxic evaluation of the medicinal plant Chenopodium ambrosioides L. Journal of Ethnopharmacology, v. 81 , n. 1, p. 11-6, 2002. http://dx.doi.org/10.1016/S03788741(01)00418-4

GANESAN, L. et al. The food colorant erythrosine is a promiscuous protein-protein interaction inhibitor. Biochemical Pharmacology, v. 81, n. 6, p. 810-8, 2011. http://dx.doi.org/10.1016/j.bcp.2010.12.020

GERAS'KIN, S. et al. Genotoxicity assay of sediment and water samples from the Upper Silesia post-mining areas, Poland by means Allium test. Chemosphere, v. 83, n. 8, p. 1133-46, 2011.

GRANT, W. F. Chromosome aberration assays in Allium. Mutation Research, v. 99, p. 273-91, 1999.

GUERRA, M.; SOUZA, M. J. Como observar os cromossomos: um guia de técnicas em citogenética vegetal, animal e humana. Ribeirão Preto: FUNPEC, 2002.

HERRERO, O.; PEREZ, J. M. M.; FERNÁNDEZ, P. F. Toxicological evaluation of three contaminant of emerging concern by use of Allium cepa test. Mutation Research, v. 743, n. 1-2, p. 24-34, 2012.

IGANCI, J. R. V. et al. Efeito do extrato aquoso de diferentes espécies de boldo sobre a germinação índice mitótico de Allium cepa L. Arquivos do Instituto de Biologia, v. 73, n. 1, p. 79-82, 2006.

LEME, D. M.; MARIN-MORALES, M. A. Chromosome aberration and micronucleus frequencies in Allium cepa cells exposed to petroleum polluted water - a case study. Mutation Research, v. 650, p. 80-86, 2008. http://dx.doi.org/10.1016/j.mrgentox.2007.10.006

MARMITT, S.; PIROTTA, V.; STULP, S. Aplicação de fotólise direta e $\mathrm{UV} / \mathrm{H} 2 \mathrm{O} 2$ a efluente sintéticos contendo diferentes corantes 
alimentícios. Química Nova, v. 33, n. 2, p. 384-88, 2010. http:// dx.doi.org/10.1590/S0100-40422010000200027

MATSUMOTO, S. T. et al. Genotoxixity and mutagenicity of water contamined with tannery, as evaluated by the micronucleus test and comet assay using the fish Oreochromis niloticus and chromosome aberration in onion root-tips. Genetics and Molecular Biology, v. 29, p. 148-58, 2006. http://dx.doi.org/10.1590/S141547572006000100028

MEINICKE, R. M. Estudo da produção de pigmentos por Monascus ruber cct 3802 utilizando glicerol como substrato em cultivo submerso. 2008. Dissertação (Mestrado)-Universidade Federal de Santa Catarina, Florianópolis, 2008.

MORRISON, J. M.; WRIGHT, C. M.; JOHN, G. H. Identification, isolation and characterization of a novel azoreductase from Clostridium perfringens. Anaerobe, v. 18, n. 2, p. 229-34, 2012. http://dx.doi.org/10.1016/j.anaerobe.2011.12.006

MOUTINHO, I. L. S.; BERTGES L. C.; ASSIS, R. V. C. Prolonged use of food dye tartrazine (FD\&C yellow n5) and its effects on the gastric mucosa of Wistar rats. Brazilian Journal Biology, v. 67, p. 141-5, 2007.http://dx.doi.org/10.1590/S1519-69842007000100019

MPOUNTOUKAS, P. et al. Cytogenetics evaluation and DNA interaction studies of the food colorants amaranth erythrosine and tartrazine. Food and Chemical Toxicology, v. 48, n. 10, p. 2834-44, 2010. http://dx.doi.org/10.1016/j.fct.2010.07.030

NI, Y.; WANG, Y.; KOKOT, S. Simultaneous kinetic spectrophotometric analysis synthetic food colorants with the aid of chemometrics. Talanta, v. 78, n. 2, p. 432-41, 2009. http://dx.doi.org/10.1016/j. talanta.2008.11.035

NUNES, E. A. et al. Genotoxic assessmernt on river water using diferent biologycal systems. Chemophere, v. 84, n. 1, p. 47-53, 2011. http:// dx.doi.org/10.1016/j.chemosphere.2011.02.085

PERON, A. P.; MARCU, M. C.; VICENTINI, V. E. P. Avaliação do potencial citotóxico dos chás de Camellia sinensis L.. e Cassia angustifolia vahl em sistema teste vegetal. Arquivas de Ciências da Saúde da Unipar, v. 12, n. 1, p. 1-10, 2008.

POLÔNIO, M. L. T.; PERES, F. Consumo de aditivos alimentares e efeitos à saúde: desafios para a saúde pública brasileira. Caderno de Saúde Pública, v. 25, n. 8, 2009.

POUL, M. et al. Lack of genotoxic effect of food dyes amaranth, susnset yellow and tartrazine and their metabolites in the gut micronucleus assay in mice. Food and Chemical Toxicology, v. 47, n. 2, p. 4438, 2009. http://dx.doi.org/10.1016/j.fct.2008.11.034
ORSOLIN, P. C.; NEPOMUCENO, J. C. Potencial carcinogênico do açafrão (Curcuma longa L.) identificado por meio do teste para detecção de clones de tumor em Drosophila melanogaster. Revista do Núcleo Interdisciplinar de Pesquisa e Extensão do UNIPAM, v. 6, p. 55-69, 2009.

RUTKUNAS, V.; SABALIAUSKAS, V.; MIZUTANI, H. Effects of diferent food colorants and polishing techniques on color stability of provisional prosthetic material. Dental Materials Journal, v. 29, n. 2, p. 167-76, 2010. http://dx.doi.org/10.4012/dmj.2009-075

SARIKAYA, R.; SELVI, M.; ERKOÇ, F. Evaluation of potencial genotoxicity of five food dyes using the somatic mutation and recombination test. Chemosphere, v. 88, n. 8, p. 974-9, 2012. http:// dx.doi.org/10.1016/j.chemosphere.2012.03.032

SASAKI, Y. F. et al. The comet with 8 mouse organs: results with 39 currently used food additives. Mutation Research, v. 519, p. 103-19, 2002. http://dx.doi.org/10.1016/S1383-5718(02)00128-6

SARDI, M. et al. Use of retailer fidelity card schemes in the assessment of food additive intake: sunset yellow a case study. Food Additivies \& Contaminants, v. 27, n. 11, p. 1507-15, 2010. http://dx.doi.org/1 0.1080/19440049.2010.495728

SAYED, H. M. et al. The modifying effect of selenium and vitamins $\mathrm{A}, \mathrm{C}$ and $\mathrm{E}$ on the genotoxicity induced by sunset yellow in male mice. Mutation Research, v. 744, n. 2, p.145-53, 2012. http://dx.doi. org/10.1016/j.mrgentox.2012.02.003

SHIMADA, C. et al. Differential colon DNA damage induced by azo food additives between rats and mice. The Journal of Toxicology Sciences, v. 35, n. 4, p. 547-54, 2010. http://dx.doi.org/10.2131/ jts.35.547

SILVA, N. O.; REED, E. Estudos sobre corantes artificiais em alimentos: quais os riscos mais comuns pelo consumo excessivo. Cadernos de Educação, Tecnologia e Sociedade, v. 2, n. 1, p. 10-4.

TABREZ, S. et al. Genotoxicity testing and biomarker studies on surface water: an over view of the techniques and their efficacies. Environmental Carcinogenesis Ecotoxicology Review, v. 29, n. 3, p. 250-75, 2011.

VICENTINI, V. E. P. et al. Averrhoa carambola L., Syzygium cumini L. Skeels and Cissus sicyoides L.: medicinal herbal tea effects on vegetal and test systems. Acta Scientiarum, v. 23, p. 593-598, 2001.

WORLD HEALTH ORGANIZATION - WHO. Evaluation of certain food additives. Geneva: WHO Technical Report Series, 2005. 